\title{
General Overview of Central Asian Turk's Art of War and Psychology of War
}

\author{
Serkan Künü \\ Iğdır University, Iğdır, Turkey \\ Andaç Karabulut \\ Gelisim University, Istanbul, Turkey
}

\begin{abstract}
In Central Asian Turkish culture, Turkish nomadic and hunting strategies in the war hold an important place in the affected areas. Lightweight equipment and horses and horseback archery have gained importance in the battle field; factors such as the independence and freedom of the Turkish military have been a source of their courage. Metehan, Oguz, Kursad and 40 warriors on the battlefield have been found in this direction and their struggle for independence period with the Central Asian countries has played an influential role in determining the boundaries. In this research, it has been tried to mention the structure of the Central Asian Turkish army, the structure of the Turkish army and logic of the war psychology.
\end{abstract}

Keywords: Central Asian Turks, Nomadic, arrow and bow, Metehan, Kursad rebellion, the Turkish Army, history, intelligence

\section{Introduction}

Central Asian Nomadic Turks' perception and management system of the state show more differences than other states. Lifestyle of the Central Asia Turks, in the absence of a life resident of the Central Asia Turks, is affected by the weapons they use in the field of battle strategies.

Central Asian Turks lead a nomadic life and the nature of dealing with livestock and land has been useful in recognition. In addition, the Central Asian Turks who struggle with difficult climatic conditions could also have learned how to be camouflaged in land. As Nomadic lifestyle of the Central Asia Turks, the other positive impact is their ability to act quickly in the battle; they use weapons and equipment that are lightweight and practical. Nomadism meant to be constantly on the move, because it is obvious that they cannot act with heavy loads. In this regard, fast horses and light equipment are the value of the Turks which have been indispensable tools.

In the article Cart in Turkish Culture, Mahmud of Kashgar talked about horses and Turks bond: "Horse is Turk's wing" (Şahin, 2005, p. 1). Nomadic life at the same time, has earned the distinction of being organized to Turkish tribes in a short time.

\footnotetext{
Serkan Künü, Ph.D., assistant professor, lecturer in Faculty of Economics and Business Administration, Department of Economics, Iğdır University, Iğdır, Turkey.

Expert Andaç Karabulut, Ph.D. student, expert in International Relations, Political Science and International Relations, Gelisim University, Istanbul, Turkey.

Correspondence concerning this article should be addressed to Dr. Serkan Künü, Iğdır University, Iğdır, Turkey. E-mail: emikail@turansam.org.
} 
By Asian Hun Emperor Metehan, an organized army was established at the first time in 209 BC. This organizational history of the Turkish army was adopted as the foundation of the Turkish Land Forces. Metehan established decimal system for the Turkish army. In this organization, name of division was included in the literature of the largest contingent of 10,000 people. There are 1,000,100 and 10 divisions, including the gradual and systematic ones in Central Asia, taking place in a structure, the effect has continued till today (Retrieved from http://www.tsk.tr/1_tsk_hakkinda/1_1_tarihce/tarihce.htm). In this regard, Kursad and Gokturks have also been organized with a strong army.

Powerful army in the war, though of great importance and reasonable equipment such as Metehan, has been especially effective commander in the Middle East and the rulers, military psychology gave the military importance of coordination and communication. Central Asian Turks in the battle field can mention the war of psychology, history of literature indicating the Turks of Central Asia. Namely, Kursad and 40 soldiers cannot defeat even knowing to fight this case with thousands of Chinese army, prior to the Metehan war developing strategies on the battlefield enemy psychology fatigue; Oguz has already made the operations in night raids and enemy soldiers panic bites are among the topics of this study.

\section{Literature Review}

Turks martial arts tactics and strategies during the period between $220 \mathrm{BC}$ and $216 \mathrm{AD}$ have become clear with Turks Hun period. Teoman was found against China that provided the unity among the Turkish tribes, dealing with internal unrest in the attack. However, by the year 209 BC, Metehan had won against deception, distraction and pressure tactics of the Chinese. Mete has made war with the Tatung-Fi and China has a remarkable special place in Turkish history. Mete's army of 30 thousands army had defeated China's army of 320 thousands (Yilmaz, 2009, p. 11).

Mete's army discussed Tanrikutu's palace in the first month of each year and the fifth month of the military state meet in Mumçiğit. Army's weapons and equipment construction would take place in the center of the Tiyanş (Yilmaz, 2009, p. 14).

Organizations of Central Asian Turkish army and battle strategies were written at that time and mentioned in the saga. When looking at the structure of the army Oguz, the army is said to be entirely composed of soldiers on horseback. Oguz cavalry could be divided into two wings with the right and left which are described to attack the enemy on the battlefield. In explaining this situation of Oguz epic, three-arrows in the hands had political advantage which was considered more honorable if seen located on the right wing (Sümer, 1992, p. 293).

Professor Sümer (1992, p. 293) explained Malik with Saluda that Oguz was shocked of the boiler of the disposition of the army in the war: Saluda at the center of the chest wins in the right arm while his brother Karan Begin wins the day, the head of the arrows on the left arm-Boz Crazy Dundar. Gentlemen on horseback in melee, whirling idyll is at war.

Oguz's war strategy is also mentioned in the book Mahmud of Kashgars Divan-i Lugati't Turks, for example, a raid into the hands of the Uighurs is listed as follows: We've raided at night, we entered into an ambush on all sides. Indeed, their ancestors have cut bangs and Minglak has killed sooner (Korkmaz, 1995, p. 258).

Kutadgu Bilig is among the most important sources of Turks cultural history, information of which helps people to reach happy working that matters. In this work, knowledge and understanding of the war are 
described with the stated strategy. Kutadgu Bilig is stated and how it should be in the control of Ögdülmiş criteria is also reported to the managers and commanders. The issues stated in the commander's war casualties inflicted on the enemy in order to be cautious. In addition, commanders also give importance to physical appearance, which is in line with this ideal Kutadgu Bilig brave commander's physical appearance, imposing, hair-beard, and manly as properly explained. Also on the battlefield, the importance of fraud is also made. Ögdülmiş on the battlefield by experienced people is indicated as who has bleached hair and beard (Göksu, 2009, pp. 268-270).

\section{Research Method}

Metehan is the emperor from $209 \mathrm{BC}$ to $174 \mathrm{BC}$ during the reign of Central Asia, Anatolia, and it has its presence felt in various parts of the world. Performed by Metehan, it affected great time in China and China has been adversely. Several expeditions to China with tactics of Metehan regulate the actual war strategy revealed by the large Chinese expedition.

Emperor Kao had sent an envoy of ten people to Mete delegation. However, these apostles were appointed as a spy and they weren't designated for the purpose of legation. The emperor of China encouraged spies to attack the army showing the weakness and Mete detects this condition. Mete's skinny military had possession headquarters and the scrawny horses in the stables (Güzel, Çiçek, \& Koca, 2002, p. 1064).

Metehan's troops faced with the Chinese troops and the Chinese army was eroded. Metehan's troops were tired and ambushed on the route that was taken by the Chinese army. Then the hit-and-run tactics against Metehan happened. Pe-Teng ran up to the mountains before troops of China cavalry have come to foot, and weary pedestrians armies had been left behind. Chinese army was deregulated (Güzel et al., 2002, p. 1064).

Chinese emperor, after the encounter, had been staying in the highlands with Metehan Pe-teng. Metehan was surprised by the tactics of the Chinese emperor. With the army of 400 thousand of Metehan, Pe-teng had surrounded the Chinese emperor in the highlands (Güzel et al., 2002, p. 1605).

Metehan was meticulous in providing strategy in the organization of the army. On the battlefield, Metehan is aware of the rapid movement of the armies in the field, and pays attention to the trail and identifying strategies that would lead the army. This strategy of Chinese martial arts master Tzu is confirmed by the following words: "There are such maneuvers that a few people can beat a whole army; on the other hand he can beat a whole army movement. The important thing is to calculate the best move" (Tzu, 2008, p.78).

Mete's siege continued for seven days due to the Chinese army's broken morale, as stated in the literature. Metehan's ambush continued for seven days.

The aim of the war and the enemy's will to dominate every vehicle are imposing its will on the enemy. For this to be done first to break the will of the enemy and to destroy the interior is to break the enemy's will, and also to break down and spirituality subversive distressing situations is required. (Güzel, et al., 2002, p. 1066)

In general paradigms, wars would be defeated by gun. The idea takes place, but Metehan partially refuted this argument. Psychological pressure on the enemy army weakened the faith and consciousness on the battlefield, and battlefield of psychology reveals how important that was. Metehan sought decisive victory with minimum casualties.

\section{Results}

Gokturk Kagan dynasty had faced a great threat with the ambition to show the beginning of the Gokturk 
Khanate. China took advantage of this situation in the year 630 and the eastern regions of Turks seized the heaven. China's invasion was a result of the movement in 630 years and Kursad with Fu-Li had fallen into the hands of China. Emperor Tang as the palace guard had been assigned, although Kursad was indispensable for the independence (Işıldak, 2010, p. 24).

Kursad had set up a secret organization with 40 valiant as a love of independence. The aim of the Turkish nation for survival was to escape persecution in China. So was the nation's deep bouncer. Kursad and 40 warriors had established a valiant plan. In this plan, Tai-tsung got his captors and captives were to save Turks around town. However, they had not come from the ruler of the palace due to the torrential rain. This plan is heard likely by the Tai-tsung and the Turkish massacre of uneasiness took place. Then 40 valiants who were living with Kursad decided to attack the palace. The attack on the palace suffered heavy casualties in Kursad and 40 warriors were killed in a vibrant river (Işs1dak, 2010, p. 24).

A movement value, in considering the results which were signaled by Kürşad Turkishness, save it, for movement is greater Kürşad, which is measured by the sacrifice and heroism. Kursad is still great. In short, it is very huge. So great ... no jealousy can reach it. (Nihal, 2013)

\section{Analysis}

The most effective weapons of that period were the battlefield arrows, bows, and swords. But the Central Asia Turks used the bow and arrow hunting, so that war has been an advantage to the Turks in the fields. Turks had gained a variety of weapons over time, for instance, stresses that are difficult to double curved to reflex springs. Despite those skilled in archery on horseback, the Turks have won four lights feature archery, along with the Huns "whistling arrows" barbed arrowheads which have been involved in the battle field (Kemal, 2014).

Archery on horseback on the battlefield and fast maneuvering were used in the fields of attrition of the enemy, but in the pedestrian union spear, sword close communication types (chest to chest) were used as weapons. Javelin of the former Turkish society is known as an indispensable weapon.

Oguz was used in arrows, swords, pikes (bayonets, cida) and rods (mace, mace). Defense shield was girded as a weapon, armor and Isuk back (to tuğulga). Oguz was made from beech wood arrows as the most effective weapon on the battlefield which is located in the saga. Arrowhead located behind the vest was called feathers at the end of the track. In Belig, the capacity was (as set by the arrows container) 80 to 90 arrows. It is an old Turkish specified as effective word bayonets and other weapons on the battlefield. Cide is the Mongolian word. In this regard, it is possible to specify that the use of the Mongols was originally a weapon. Oguz is an important weapon in rods of the assault weapons (Sümer, 1992, p. 294).

As mentioned in earlier, Metehan would give importance to psychology and the enemy on the battlefield. Located in the literature of his own invention read sergeant (whistling arrow), Mete was given ten thousands of army. Metehan gave a direction arrow, and if he did so, all the soldiers under his command had to read translations in other areas where are Mete's orientation. Some of the soldiers hesitated. Thereupon they read sequentially turned on those who hesitated. People who hesitated to shoot arrows at each of the soldiers were killed with arrows. Since they were so small, "starring read dial destination" game also clinched orders (The Free Encyclopedia, 2013).

Intelligence is in gathering information of retrieval concepts in the literature on the taxpayers, against receiving information in the structure which has been systematically well done organized. Old Turks, Chinese 
commanders, the Sultan of the Prophets were important as intelligence. Concern for the intelligence of the secret organization operates effectively against their countries and communities have committed to use (Karabulut, 2013, p. 64).

Steppe culture and deep-rooted tradition are included if having the oldest of the known properties of the Turks, nomadic life and hunting. Old Turks were hunting animals and understand the language of the people who have created with the belief of secret language hunters (Kadriye, 2008, pp. 70-71). Old Turks were hunting and fishing against a private encrypted communications. Thus intelligence with the need is noticed and it is possible to specify that they have done. For Turks, intelligence has always been important, after the transition to settle life in the old Turkish espionage elements called Casita (Çaşut). Casita, among the Turks was used in the meaning of "hide a secret saying something" (Ilter, 2002).

In Central Asia, the Mongols and the Turks were living together. Common culture is the way of life of the similarity because the Mongol ruled Kublai Khan's intelligence structure in Central Asia, which is able to be the example of intelligence and military strategies (Eberhed, 1943, pp. 24-25). Kublai Khan was made to Japan in 1281 after failing the first time and the second time gave importance to the diplomats and intelligence services. Acts of Kublai Khan submit to the intelligence in the reports; the fear of Japanese warfare, civil unrest and state administration dichotomy was thought to exist between Kyoto and Kamakura.

\section{Conclusions}

Nomadic Turkish tribe of Central Asia has become an important means of transportation due to experience of riding horses. Transportation by horse shows effectiveness in areas as fast transport and easy way to maneuver on the battlefield due to its high level, which has become an indispensable element. These elements of integrity with bows and arrows have led to the existence of a powerful army in the Middle East.

The presence of a strong army doesn't use only one weapon. Central Asia has been a different place in history that influences the determination of the limits of the period when Metehan is consistent with the expertise and strategies. Metehan has huge casualties that the only weapon on the battlefield and the enemy army to act depend on the number of psychology and psychology of his army in defiance of China.

Metehan, aimed at decisive victory with minimal cost and losses, can be realized by interpreting his strategies. Light weapons and their commitment to the army to win granted that Metehan is another dimension of effectiveness on the battlefield. Subsequently, the Central Asian Turks cannot live under the oppression structure of the reason which may indicate a nomadic life. In this case, the Turks fought on the battlefield by targeting for victory.

Freedom and independence just are not a feeling for Metehan army. Kursad and 40 warriors also experienced these feelings when killed by obtaining the mission. China aims to rescue from the tyranny of the Turkish race and 40 warriors of Kursad. China and the Central Asia Turks have been deeply devoted. Kursad and 40 warriorss with thousands of soldiers' independence or death rhetoric fight have a holy place in history literature.

\section{References}

Turkish Armed Forces. (2014). Chief of general staff of Turkish Armed Forces: History. Retrieved from http://www.tsk.tr/1_tsk_hakkinda/1_1_tarihce/tarihce.htm

Eberhed. W. (1943). Ancient Chinese culture and Turks. Ankara Journal of Language, 4, 24-25.

Göksu, E. (2009). Turkey, art of war by Kutadgu Bilig. International Journal of Social Research, 2(6), 268-270. 
Güzel, H. C., Çiçek, K., \& Koca. S. (2002). Turks. Ankara: New Turkey Publications.

Ilter, E. (2002). National intelligence history. Ankara: Mit Publications.

Iş1ldak, S. (2010). Kürşat revolution. Youth hostel Information Journal, 20, 24-24.

Kadriye, T. (2008). Azeri cult and ava in tables understanding. Ankara: Traditional Publishing.

Karabulut, A. (2013). Intelligence in world history. Journal of Human Turan, 5, 18-64.

Kemal, S. C. (2014). Strategies of war and war in ancient Turkey. Retrieved from http://www.bilinmeyenturktarihi.com/ eski-turklerde-savas-ve-savas-stratejileri.html

Korkmaz, Z. (1995). Vocabulary of Kasgarh Mahmud and DivanuLugati'tTürk. Ankara: Turkish Language Institute Publisher.

Nihal, A. (2013). The greatest Turk hero: Kursad. Retrieved from http://www.nihal-atsiz.com/yazi/ en-buyuk-turk-kahramani-kursad-h-nihal-atsiz.html

Şahin, U. Ş. (2005). Cart in Turkish culture. Bilig Journal, 32, 1-1.

Sümer, F. (1992). Oguz: Turkmens. İstanbul: Turkish World Research Foundation Publisher.

The Free Encyclopedia. (2013). Hun Biography. Retrieved from http://zh.wikisource.org/wiki/\%E5\%8F\%B2\% E8\%A8\%98/\%E5\%8D\%B7110

Türkan, K. (2008). Azeris stories. Hunting and Hunting Understanding, 8, 70-71.

Tzu, S. (2008). Martial arts. Istanbul: Key Books Publisher.

Y1lmaz, S. (2009). Turkish art of war and strategy. Geopolitical Strategy Monthly Magazine, 62, 11-14. 